\title{
НОВА (ГЕО)ПОЛИТИЧКА РАСКРСНИЦА СРБИЈЕ 1
}

\author{
проф. др Мирослав Младеновић ${ }^{2}$ \\ проф. др Јелена Георгијевна Пономарева ${ }^{3}$
}

\section{Апстракт}

Као ко зна колико пута у историји, Балкан је и даље зона стратешког прегруписавања и надметања. Борба водећих актера светске политике посебно је фокусирана на политички и војно и даље релативно неутралну Србију. Београд, упркос озбиљним потресима на прелазу из 20. у 21. век (крвава демонтажа Југославије, НАТО агресија, „развод“ са Црном Гором, стварање „Републике Косова“), још увек успева да балансира између два главна пола привлачности: с једне стране ЕУ и НАТО, а са друге Русије, што се уклапа у концепт њене мултивекторске спољне политике. Упркос географској, историјској, културној и економској предодређености за европске интеграције, коначни избор Србије за ту опцију оптерећују два веома битна момента: потреба да се призна „Република Косово“ и (што је тренутно мање експлицитно изражено, али свакако присутно) да се земља укључи у војно-политички оквир НАТО-а. Прво питање носи са собом значајне политичке и цивилизацијске ризике, како за Западни Балкан, тако и за целу Европску унију, а ту је и озбиљан унутрашњи раскол српског друштва у погледу могућности признавања новог албанског ентитета. Други моменат је оптерећен и даље свежим сећањима на антицивилизацијска агресивна борбена дејства земаља НАТО-а. Природни баланс евроатлантског притиска на Београд чини Русија. Она има јединствене могућности за стварање доброг имиџа и, за разлику од ЕУ, нема карактеристике „царства по позиву“. Међутим, постојећи историјски дуализам нарушава се појавом новог играча на Балкану - Народне Републике Кине (НРК). Пекинг користи искључиво економске полуге за решавање стратешких задатака продора на европска тржишта и истовремено глатко, али веома успешно, истискује Русију као главну алтернативу западној оријентацији Србије.

Кључне речи: Србија, Европска унија, НАТО, Русија, Народна Република Кина, спољна политика, неутралност

\footnotetext{
1 Чланак је резултат рада на пројекту Министарства просвете, науке и технолошког развоја Републике Србије, на основу потписаног Уговора о реализацији и финансирању НИО у 2020. години, као и Плана рада НИО Факултета безбедности за 2020. годину.

2 Редовни професор, Универзитет у Београду, Факултет безбедности.

Е-пошта: m.mladenovic@fb.bg.ac.rs

3 Редовни професор, Московски државни институт (универзитет) за међународне односе при Министарству спољних послова Руске Федерације (МГИМО). Е-пошта: nastya304@mail.ru
} 
Балкан је вековима био и остао турбулентна зона светске политике, која је у великој мери одређена историјским наслеђем. Истовремено, потенцијал нестабилности који се уочава и у садашњости, узрокован је сударима интереса водећих актера нашег времена: држава, наднационалних и транснационалних структура, као и не увек легалним чиниоцима - представницима међународног тероризма и уско повезаног са њим, све активнијег интернационалног криминала.

Србија, као средишња и најзначајнија држава Западног Балкана, у фокусу је стратегије евроатлантске интеграције. У исто време, избор овог вектора развоја за српско друштво је још увек оптерећен бројним нерешеним питањима која, с једне стране, значајно усложњавају процес приступања ЕУ, а са друге детерминишу потребу вођења политике војне неутралности и мултивекторности, што земљи омогућава да сачува релативну независност и значај у међународној арени.

\section{МУЛТИВЕКТОРНОСТ КАО ПОЛИТИКА ОПСТАНКА}

Историја и садашњост повезаности балканских и европских земаља пуна је контрадикторности. Без сумње, најтежи дијалог са Европом ипак је имала Србија. Два пута у двадесетом веку (Први и Други светски рат) Србија се нашла у рововима против Другог и Трећег рајха и његових савезника, али је након тих борби ипак била у групи победника. Резултат геополитичких исхода крвавих битака била је трансформација Србије у језгра балканских „царстава“ Краљевине (1918-1941) и Социјалистичке (1945-1991) Југославије. Последице рушења Југославија испољиле су се као национална трагедија за Србију и Србе. Они нису само поражени у балканским ратовима модерног времена, у Хрватској и Босни, већ су преживели деценију санкција и 78 дана бомбардовања током НАТО агресије. У тим процесима, изгубили су контролу над Косовом и Метохијом родним местом средњовековне српске државности.

Колективна подршка Запада „косовском пројекту“ тешко је трауматизовала српску представу о њеној европској припадности. ${ }^{5}$ Историја се поновила у новој трагедији: питање Косова постало је вододелница балканске стварности, фиксирајући је као идентификациони код већине Срба („Косово је Србија“), али и као однос према великој Европи. Крхка државотворност, која је преостала уништавањем интегралне државе (у почетку значајним утапањем у различите облике југословенства, а касније насилним одузимањем њене историјске

4 Шире о политици мултивекторности Србије видети у: Пономарева, Е. Г. и Младенович, M. Сербия: Многовекторность как выход из тупика старегической уязвимости, Сравнителная политика . 2020 T.11 № 1, Москва, eLIBRARY ID: 32289, стр. 88-103

5 Видети шире у: Пономарева Е.Г. Проект «Косово» и большая политика // Мир и политика. 2013. № 7 (82). С. 92-111 
територије), пројектовала је стратешку рањивост Србије. Поприлично уски маневарски простор унутрашње и спољне политике гура Србију (попут већине „постсоцијалистичких“ земаља) у наручје „царства по позиву“, које ће преузети улогу ментора и браниоца под прилично строгим и ограничавајућим условима. ${ }^{6}$

За разлику од других „нових демократија“, Србија и даље избегава коначни избор мецене и покушава да спроводи вишевекторску политику, која јој омогућава да одржи стабилност политичког режима, балансирањем између интереса водећих актера светске политике (пре свега Немачке, ЕУ, Кине, Русије, САД, Француске, Велике Британије, Турске). Уз све потешкоће и критике, вишевекторска политика, ако је вешта и суптилна, може да омогући „малим нацијама“ да заштите своје интересе и да максимално релаксирају спољнополитичку зависност. ${ }^{7}$ Многовекторност није новина. Земље Централне Азије оријентишу своје спољне политике и ка Русији и према Кини. На постсовјетском Кавказу, као главни вектори, уочавају се Русија, Турска и САД. За Србију су то (не занемарујући ни једну од горе споменутих земаља) пре свега: ЕУ, САД и Русија.

\section{Три вектора српске спољне политике}

Анализа тренутне ситуације открива три главна могућа правца развоја савремене Србије. Први је евроатлантска интеграција, која упркос очигледној кризи, почев од 2000. године, и даље остаје приоритет за званични Београд. Избор ЕУ као „царства по позиву“ несумњиво захтева признање Републике Косова и вероватни (иако не и обавезни) каснији улазак у НАТО. „Избор цивилизацијског курса развоја, однос Балкана према Европи и обрнуто - Европе према Балкану, представља свеобухватну противречност живота региона и узрок крутих цик-цак заокрета његове историје и садашњости“. 8

Други вектор - баланс је руски; дефинисан, не толико економским, колико културним, историјским и политичким факторима. Међутим, одржавање конкурентске присутности захтева од Русије озбиљне напоре и конкретне предлоге за формулисање новог начина рада, што подразумева примену ефикаснијих метода спољнополитичке активности. Примена овог приступа је немогућа без јасног дефинисања националних интереса Русије у овом региону, постављања циљева и примене одговарајућих ресурса, метода и технологије спољнополитичке делатности и утицаја. На основу тога, могуће је формирати стратегију присуства и дефинисати начине заштите и реализације својих

${ }^{6}$ Lundestad, G. Empire by Invitation? The United States and Western Europe, 1945-1952 // Journal of Peace Research, 1986, Vol. 23, No. 3, pp. 263-277.

7 Colomer, J.M. Great Empires, Small Nations: The Uncertain Future of the Sovereign State. L., N.Y.: Routledge, 2007. 114 p.

8 Вишняков Я.В., Пономарева Е.Г. Сербия на Балканах: изобретение «порохового погреба Европы» // Современная Европа. 2018. № 7. С. 119. 
интереса у Србији и у целом балканском региону, не само на савременој етапи, већ и у будућности.

Трећи вектор је Кина. Док традиционални геополитички играчи на Балкану у први план стављају историјску компоненту и покушавају на фобијама балканских народа да граде своје стратегије, Кина искључиво економским средствима повећава своје присуство у региону. Вредност Пекинга за Србију и друге земље у окружењу није само у финансијској привлачности и ефикасности (одлуке о пројектима, у поређењу са Русијом, ЕУ и САД, доносе се у врло кратком року), већ и у политичкој неутралности.

Европски вектор је рационалан избор Србије из више разлога: политички, географски, економски, културолошки. Ово опредељење је формализовано ратификацијом Споразума о придруживању и стабилизацији од стране српског парламента 9. септембра 2008. године.

Од 22. децембра 2009. године, када је званично поднет захтев за улазак земље у ЕУ, започет је тежак процес приближавања „царству по позиву“. Може се рећи да је Београд испунио готово све услове чланства, укључујући и процес нормализације односа са „Републиком Косово“. Такозвани Берлински процес, покренут у августу 2014. (након делимичног запостављања региона), поставио је три главна циља: коначно решавање акутних политичких спорова (укључујући признање „Републике Косово“), модернизацију економије и убрзање демократских процеса. ${ }^{9}$ Глобална стратегија из 2016. године наглашава: „чланство у ЕУ је могуће, али под предвиђеним условима за то“.10

Упркос напорима обе стране, Берлински процес не оптерећују само политички спорови, већ и тешки социјални, економски и институционални проблеми. Покушај реанимације извршен је почетком 2018. године, када је Европска комисија упутила Европском парламенту на усвајање документ под називом „Веродостојна перспектива проширења за Западни Балкан и појачано ангажовање ЕУ на Западном Балкану“.11 Актом се, оптимистички, одређује 2025. година као могући рок за придруживање Србије и Црне Горе ЕУ. Међутим, већ крајем 2018. године постало је очигледно да ови рокови нису оствариви и то, не само због унутарбалканских разлога.

Еуфемистички наговештаји француског председника Е. Макрона о сложености процеса интеграције Србије због неопходности „реформисања ЕУ“, изражени

9 Final Declaration by the Chair of the Conference on the Western Balkans. Berlin. 28 August 2014., https://www.auswaertiges-amt. de/blob/264688/953e9f4b2f0b008d20bf6a65bfb 4ebbe/140828-abschlusserkl-konf-westl-balkan-data.pdf, , /09/05/2020.

10 Shared Vision, Common Action: A Stronger Europe. A Global Strategy for European Union's Foreign and Security Policy. European Union External Action. June 2016. Mode of access: https://eeas.europa.eu/sites/eeas/files/eugs_review_web.pdf

11 Саиопштење Комисије упућено Европском парламенту, Савету, Европском економском и социјалном комитету и Комитету региона, https://www.mos.gov.rs/public/ck/uploads/files/EU\%20Strategija\%20prosirenja\%20zapad ni\%20Balkan\%202018.pdf, (посећено 04.05.2020) 
током посете Београду у јулу 2019. године нису били велико изненађење за српско руководство.

Истовремено, као и Брисел, ни само српско друштво у овом моменту није баш одушевљено могућим чланством Србије у ЕУ. Истраживање које је спроведено међу младима Западног Балкана показује да је највиши проценат подршке приступању ЕУ изражен у Албанији - 94,5\% и на Косову - 88,9\%. Следе Босна и Херцеговина (84,9\%), Северна Македонија (81\%) и Црна Гора $(77,2 \%)$. Србија заузима последњу позицију на овој листи - 56,1\%.12 Тренутно је без сумње главна препрека наставку процеса европских интеграција Србије судбина аутономне покрајине Косово и Метохија. Косовско питање је за Србију најосетљивије, не само у контексту „берлинске тријаде“ и у односа са НАТО-ом, већ и у оквиру развоја стратешког партнерства са Русијом, која се залаже „за постизање одрживог и обострано прихватљивог решења за Београд и Приштину, на основу Резолуције 1244 СБ ОУН“.13 Међутим, у решавању овог проблема, све активније се на страни Албанаца укључују ванрегионални субјекти: пре свега САД, али и земље Блиског Истока.

Фебруара 2018. године, министар спољних послова СР Немачке, 3. Габриел је веома јасно, иако не баш дипломатски, обелоданио став најзначајније чланице ЕУ по питању виђења косовског проблема: „Србија не може постати део ЕУ без признавања независности Косова.“14 Суштински исто, мада не тако експлицитно, и француски председник Е. Макрон је говорио о неизбежности „компромиса“ са Републиком Косово као фактором европске будућности Србије.

На тај начин постаје све очигледније да је признавање још једне албанске државе предуслов за евроинтеграцију, без обзира на то што више од 80\% Срба није спремно да прихвати такву цену уласка у ЕУ15.

Сву сложеност косовског проблема и исхитреност решења од стране „међународне заједнице“ драстично је показала идеја о евентуалној размени територија између Београда и Приштине. Поново се показало да у том процесу свако има своје идеје, интересе и планове, а да ситуација око јужне српске покрајине ни изблиза није била зрело размотрена. Она је, чини се, била само добар повод за реализацију сопствених интереса спољних учесника. После сусрета српског и косовског председника на Европском форуму у Аустрији, августа 2018. године, припремљене су чак и релевантне мапе поделе територија.

12 Istraživačko-izdavački centar Demostat, Više žele u Evropu nego da im zemlja uđe u EU http://demostat.rs/sr/vesti/istrazivanja/ vise-zele-u-evropu-nego-da-im-zemlja-udeu-eu/660, /08/08/2020.

13 Пресс-конференция В. Путина и А. Вучича. 17 января 2019.г, http://www.kremlin.ru/events/president/ news/59693, /09/05/2020.

${ }^{14}$ Агенција LIFE, Глава МИД ФРГ: Сербия должна признать независимость Косова для вступления в EC, https://life.ru/p/1089227, /09/05/2020.

15 ИА «Новороссия», Гайич С.: Обострение в Косово - очередной этап войны Запада против Сербии и России, https://novorosinform. org/713850, /09/05/2020. 
„Пакет“ план је подразумевао свеобухватну размену територија: српске заједнице Лепосавић, Звечан и Зубин Поток (приближно једна петина територије КиМ-а) прикључују се Србији, а Косову се припајају општине са Југа Србије: Бујановац (55\% Албанаца) и Прешево (89\% Албанаца). ${ }^{16}$. Према аустријским изворима, споразум је требало да буде потписан још почетком септембра 2018. године у Бриселу, уз учешће представника ЕУ.

Међутим, за разлику од Аустрије, која сматра да :„Ако Србија и Косово могу да се договоре да промене границу, Аустрија то сигурно неће спречити“.17, немачка канцеларка је категорички наступила против тога. Са тачке гледишта званичног Берлина, „Територијални интегритет држава Западног Балкана већ је формиран и не може се мењати“.18 Идеја о размени територија изазвала је велику забринутост и у Србији, а на Косову је произвела политички раскол између присталица председника и премијера. Унутар ЕУ поново је дошло до преиспитивања ставова и кристализације разлика у ставовима држава.

Ипак, мишљење ЕУ и различити ставови држава унутар ње нису довели до замрзавања преговора и уклањања теме „разграничења“ из активног дневног реда.

„Република Косово“ представља опасност, и то не само за регион Западног Балкана. Претња се шири на читаву Европу због могуће примене универзалне технологије остваривања сепаратистичких циљева, односно - „геополитичке акупунктуре“. У односу на Балкан, „геополитичка акупунктура“ - то су елементи међународног тероризма (вехабије, милитанти „Ослободилачке војске Косова“ и „Исламске државе“). У извештају који је објавио амерички Стејт департмент указује се да је 2017. године највећи проценат милитаната који се боре у редовима „Исламске државе“ у односу на број становника долазио са Косова. Постоје тачни подаци за више од 400 људи који су са Косова отишли у Сирију и Ирак. Интересантно је да 10 до 15\% џихадиста чине жене, а међу њима, скоро $40 \%$ долази са Косова ${ }^{19}$.

Такво стање одређено је природом идеологије албанизма, која поставља „специфичан циљ - укључивање свих подручја Балкана на којима живи албанско становништво у заједнички политички оквир“. Таква идеологија подржана је ” разгранатом мафијашко-клановском структуром албанског друштва и њеном

\footnotetext{
16 Три сценария для Косово. Аналитический доклад / под ред. О. Бондаренко. Режим доступа: https://balkanist.ru/tri-stsenariya-dlya-kosovo, /09/05/2020.

17 Пудовкин Е. Гибкая граница, https://www.rbc.ru/politics/29/08/2018/5b86769b9a7947866771c72f, /09/05/2020.

18 Angela Merkel: No Balkan Border Changes, https://www.politico.eu/article/angela-merkelno-balkan-border-changeskosovo-serbia-vucic-thaci/, /09/05/2020.

19 Country Reports on Terrorism 2017., https://www.state.gov/reports/country-reportsonterrorism-2017/, /09/05/2020.
} 
укљученошћу у структуре међународног тероризма“.20 Према подацима стручњака, на Косову, на граници са Албанијом и Македонијом (подручја Ђаковице, Урошевца, Дечана, Призрена и Пећи) организовано је пет база за обуку „Исламске државе“21.

Ту долазе људи који су почетну обуку имали у џамијама, приватним школама, на обуци преко невладиних организација које финансирају арапски фондови. У камповима се финализује обука у руковању оружјем и у вођењу борбених дејстава. Обавезна војна обука укључује курсеве као што су „урбана герила“, „системи наоружања“,„израда експлозивних направа“ и сл. Захваљујући ЕУ и САДy, приштинско политичко руководство је за балканске прилике добило енормну слободу деловања. Као резултат тога, дошло је до нарушавања вековног баланса међу народима који живе у региону.

При томе, „простор експанзије“ за албански фактор данас није само јужни део Балкана (то се, по њима, подразумева), већ практично цела Европа.

Не само стручњаци, већ и политичари данас бивају све забринутији због претњи које потичу из региона. Централноафричка република је у јулу „разјаснила свој став“ о Косову и постала четрнаеста земља која је повукла признање самопроглашене републике. Чини се да је ово само почетак процеса repulsa consulates. Посланици „Алтернативе за Немачку“ покренули су у Бундестагу дискусију о ревизији статуса Косова, услед активног присуства регрутних центара и кампова за обуку на овој територији, повезаних са међународним терористичким организацијама. Такође, у априлу 2019. Парламент Холандије је великом већином изгласао повратак визног режима за албанске држављане због „повећања нивоа албанског криминала у региону “22.

Нефлексибилност и кратковидост европске бирократије иду на руку албанским иредентистима, који се све више користе као оруђе у интересу ванрегионалних играча. У таквим околностима, притисци на Србију у погледу признања Косова изгледају контрапродуктивно за процес евроинтеграција.

По свему судећи, сценарио status quo изгледа најоптималнији, јер омогућава одржавање стабилности у региону док се не постигне праведно решење које је бар донекле фер и према Србима. Потрага за таквим решењем подразумева „способност проналажења компромиса, али када се они пронађу, морају се спроводити“ 23. Ово се односи на све учеснике у процесу.

20 Пономарева Е.Г. Албанский фактор дестабилизации Западных Балкан // Вестник МГИМО-Университета. 2018. № 2(59). С. 112.

21 ISIS-Daesh Training Camps in Kosovo, Recruitment of Terrorists by NGOs, http://www.globalresearch.ca/isisdaesh-training-camps-in-kosovo-recruitment-ofterroristsby-ngos/5537652, /09/05/2020.

22 Нидерланды требуют отменить безвизовый режим ЕС для Албании, (https://sputnikgeorgia.ru/world_politics/20190604/245465012/, Niderlandy-trebuyutotmenit-bezvizovyy-rezhimES-dlya-Albanii.html, /09/05/2020.

23 Пресс-конференция В. Путина и А. Вучича. 17 января 2019 г., http://www.kremlin.ru/events/president/ news/59693., /09/05/2020. 


\section{Србија и Русија}

Русија, у окружењу таквих гиганата као што су САД и НРК, свакако не изгледа импресивно. Савремена социјално-економска и војно-техничка ситуација РФ и даље је прилично сложена, посебно ако се узме у обзир актуелни политички однос великог броја западних земаља и чињеница да су против Русије уведене различите форме санкција.

Геополитичка дефанзива Русије, која је трајала све до „обојене револуције“ у Украјини, замењена је одлучнијом и самосталнијом политиком Кремља у међународној арени.

Супротстављање једностраном проглашењу независности Косова и размештају елемената америчког противракетног система у Европи, ширење сарадње са Кином у оквиру Шангајске организације за сарадњу, повећање расхода за систем одбране, жестока реакција у сукобу са Грузијом, однос према политичким играма око Украјине и присаједињење Крима, акција у Сирији - све то сведочи о формирању руске елите, која има потпуно другачији однос и представу о корпоративним и националним интересима него што је то био случај у време тзв. јељцинског периода.

Елементарна је теоријска истина да држава постаје велики међународни субјект тек кад његов стратегијски значај и потенцијал поприме светске размере. Без обзира на то што у поређењу са САД и Кином Русија несумњиво заостаје, та држава има изузетан комплексни потенцијал. Између осталог, о могућностима Русије сведоче, не само географско-климатски положај, огромни природни ресурси, сачуван атомски штит и интелектуални потенцијал грађана, већ и историјско искуство. 24

Односи Русије и Србије су посебна целина. Због културних, историјских, друштвено-економских и политичких веза два народа, односи између Русије и Србије увек су били пријатељски, некад са више, некад мање резултата. Дипломатски односи у савременом смислу, 2018. године су обележили сто осамдесету годишњицу.

Наравно, руско-српске везе постоје још из много ранијег периода, а за њихов почетак најчешће се узима 12. век, када је Свети Сава замонашен у руском манастиру Пантелејмон на Светој Гори. Током бурних векова који су долазили, ти односи су се развијали узлазном линијом, како на политичком, верском и културном, тако и на економском плану. Период Првог светског рата и победа над фашизмом у Другом, створили су нови квалитет односа две државе и два народа.

24 Видети шире у: М. Младеновић, Е. Пономарева, Кина-Америка-Русија - глобални троугао 21. века, Социолошки преглед, Београд, YU ISSN 0085-6320, UDK 316,2011, вол. 45, бр. 4, стр. 459-476, 
Тренутно, руско-српски односи могу да се опишу као традиционално пријатељски, на нивоу стратешког партнерства. Заснивају се на „дубоком

међусобном осећају пријатељства, вишевековној историји односа, традицији језичке, духовне и културне блискости братских народа двеју земаља..." 25.

Међутим, у данашњем турбулентном свету, градити односе искључиво на привржености традиционалним везама, свакако је недовољно и немогуће. Иако Русија није „царство по позиву“, она представља веома важан вектор баланса за српску спољну политику. Она је за Београд историјски савезник са којим су, између осталог, „успостављени стратешки партнерски односи од 2013. године, који обухватају политику, трговину, економију, културу, науку, технологију и образовање“26.

Без обзира на овакав спектар, због растуће тензије у региону и повећаних сигурносних ризика и претњи, пажњу у међусобним односима све више заокупљају безбедносни проблеми, пре свега заједничка борба против међународног тероризма и развој војне и војно-техничке сарадње.

Унапређењу међусобних односа посебан квалитет даје и готово религиозни култ Путина, формиран током протеклих деценија. Руски председник је дуги низ година остао најпопуларнији страни лидер у Србији: њему верује око 57\% Срба. 27

Према испитивањима јавног мњења у Србији, у зависности од методологије израчунавања, проценат присталица сарадње са Русијом иде и до $90 \% 28$. Илустративни су и одговори на питање: „Чије војне базе могу бити од користи Србији?“ Највећи проценат испитаника - 53\%, изјаснило се за војну неутралност; $20 \%$ је за руске базе; 4\% за распоређивање руских и америчких база истовремено; $2 \%$ су подржали идеју америчког присуства; 21\% није могло да се определи. ${ }^{29}$ Нико од испитаника није изабрао НАТО базу.

Занимљиво је да велики проценат испитаника (36\%) сматра да је Русија највећи трговински партнер и инвеститор (иако је то у стварности ЕУ). Такође, 55\% Срба верује да је Русија војно јача од НАТО-а; Предност НАТО-у даје само 19\%

25 Декларация о стратегическом партнёрстве между Российской Федерацией и Республикой Сербией http://www.kremlin.ru/supplement/1461, /09/05/2020.

26 Исто, /09/05/2020.

27 Istraživanje: Vučić ubedljivo najpopularniji političar, Putinu najviše poverenja među svetskim liderima, http://www.novosti.rs/vesti/naslovna/politika/aktuelno.289.html:769462/05/05/2020.

28 Survey of Serbian Public Opinion / International Republic Institute (IRI). Mode of access: https:// www.iri.org/sites/default/files/wysiwyg/serbia_ november_2015_poll_public_release.pdf/09/05/2020.

${ }^{29}$ Kojem bi se carstvu priklonili... Srbija između Istoka i Zapada. Avgust 2017, http://demostat. rs/sr/vesti/istrazivanja/kojem-bi-se-carstvu-priklonili--srbija-izmedu-istoka-i-zapada/214, /09/05/2020. 
испитаника. ${ }^{30}$ Важни су и подаци анкете међу младима, која је показала да је интересовање за Русију око 65\%, за ЕУ - 58\% и за САД - 67\%. Најмањи и проценат - 53\% испитаника - заинтересовано је за унутарсрпске проблеме. ${ }^{31}$ Суштински гледано, у односу на ЕУ, појединачне земље Европе и на САД, Русија има значајне преференције које су, међутим, знатно изнад њеног реалног спољнополитичког присуства у региону.

Посебно место у односима две земље заузима Руско-српски хуманитарни центар у Нишу (РСХЦ), формиран на основу међувладиног споразума из 2012. године. Иако западни стручњаци и новинари од самог почетка његовог рада дају све од себе да га представе као руску војну базу, овај центар, са десетак стално запослених, веома активно делује у области превенције и реаговања на ванредне ситуације; врши обуку специјалиста из ових области; пружа помоћ жртвама ванредних ситуација и донира значајна средства субјектима система цивилне заштите Републике Србије. Од 2014. до 2018. године, Центар је помогао у обуци више од 500 стручњака за ванредне ситуације из Србије, Босне и Херцеговине и Македоније.

Упркос доброј сарадњи и њеној могућој перспективи, треба нагласити да је руско присуство и утицај у економској и војнотехничкој сфери десетинама пута мањи него ЕУ и НАТО. Главни економски партнер Србије је Европа, са 82,4\% трговинске размене, док је тај проценат 2018. године са Русијом износио 4,55\%.

Полазећи од те чињенице, Русија би морала што пре да мења свој приступ региону уколико жели да и даље буде значајно присутна у њему. Као главни иницијатор формирања Евроазијског економског савеза и земља која претендује на значајнију позицију у међународним односима, она мора да има у виду да је

30 Western Balkans: Between East and West. Public Opinion Research in Bosnia and Herzegovina, Macedonia, Montenegro, and Serbia / National Democratic Institute, 2018. https://www.ndi.org/sites/default/files, 09/05/2020.

31 Mladi i politika (Youth and Politics). Mode of access: http://demostat.rs/sr/vesti/istrazivanja/ mladi-i-politika/718, Istraživanje: Vučić ubedljivo najpopularniji političar, Putinu najviše poverenja među svetskim liderima, http://www.novosti.rs/vesti/naslovna/politika/aktuelno.289.html:769462-Istrazivanje-

Vucic-ubedljivo-najpopularniji-politicar-Putinu-najvise-poverenja-medju-svetskimliderima/05/05/2020.

31 Survey of Serbian Public Opinion / International Republic Institute (IRI). Mode of access: https:// www.iri.org/sites/default/files/wysiwyg/serbia_ november_2015_poll_public_release.pdf/09/05/2020.

31 Kojem bi se carstvu priklonili... Srbija između Istoka i Zapada. Avgust 2017, http://demostat. rs/sr/vesti/istrazivanja/kojem-bi-se-carstvu-priklonili--srbija-izmedu-istoka-i-zapada/214, /09/05/2020.

31 Western Balkans: Between East and West. Public Opinion Research in Bosnia and Herzegovina, Macedonia, Montenegro, and Serbia / National Democratic Institute, 2018. https://www.ndi.org/sites/default/files, 09/05/2020.

31 Mladi i politika (Youth and Politics). Mode of access: http://demostat.rs/sr/vesti/istrazivanja/ mladi-i-politika/718 
основни предуслов за то - употреба алтернативних, ефикасних и усмерених информационих и образовних система. То је неопходно због заштите сопствене националне безбедности и безбедности својих грађана, као и ради остваривања евроазијског интеграционог циља. У том смислу, „мека моћ“ мора да постане најважнији (у неким условима - чак одлучујући) ресурс Русије у евроазијском простору 32 .

\section{Србија и САД (НАТО)}

Улога САД у балканским поремећајима, посебно у вези са косовским питањем, заслужује засебну пажњу. Вашингтон игра своју игру, често различиту, не толико од Брисела, колико од Берлина, Лондона и Париза. Америчка политика и ставови непрекидно су присутни кроз сарадњу и контакте главних политичких представника српске позиције и опозиције са америчком амбасадом и Стејт департментом. Србија је 2015. године прихватила и ИПАП (Individual Partnership Action Plan) - оперативни споразум који је омогућио најближу сарадњу са НАТОом и фактичку могућност продирања структура алијансе у скоро све сфере делатности српске државе. Без обзира на све ово, говорити о неким превеликим изгледима америчког вектора, свакако би било погрешно. Вероватније је да се уз помоћ Вашингтона обезбеђује опстанак у оквиру унутаревропских противречности и на неки начин ствара противтежа Москви.

Власти Приштине и Тиране изабрале су нову тактику, очигледно не без консултација са Вашингтоном. Није случајно, нити самоиницијативно Харадинај изјавио да ће „Сједињене Државе, без обзира на околности, увек бити на страни Приштине, чак и ако крше све темеље међународног права“.33 По схватању премијера Албаније Е. Раме, то је нови „План А“ - који подразумева „Општу стратегију уједињења Албанаца до 2025. године“.

Ту мисао, нескривено истиче и Тачи, чак са извесном дозом претње ЕУ:,ако ЕУ не жели да прихвати две албанске државе са две заставе, онда нека прихвати само једну“. ${ }^{34}$ Растуће амбиције косовских Албанаца потиснуле су на неодређено време потписивање обавезујућег споразума“ (у терминологији ЕУ) о нормализацији односа Београда и Приштине. Такав неконструктивни приступ определио је неуспех састанка у априлу 2019. у Берлину и отказивање наставка дискусије у Паризу.

32 Видети шире у: Мирослав Младеновић, Јелена Пономарева, «Мека моћ» Русије - као услов успеха евроазијске интеграције, Српска политичка мисао број 1/2016 год. 23. vol. 51, Београд, УДК 327::911.3(497)“19/20“, стр. 11-29;

33 Борисов А.В. Косово получило свою армию //Российская газета, 14 декабря 2018, https://rg.ru/2018/12/14/kosovopoluchilo-svoiu-armiiu.html, /09/05/2020.

34 Tači preti EU formiranjem "Velike Albanije”, https://www.telegraf.rs/vesti/politika/3066812tacija-preti-eu-formiranjemvelike-albanije-ako-ne-zele-da-prihvati-dvealbanske-drzave-sadve-zastave-neka-prihvatesamo-jednu-zastavu, /09/05/2020. 
У суштини, понашање приштинских власти израз је презира према ЕУ и припрема терена за активније укључење Америке у преговоре. Без обзира на могуће нијансе америчког приступа српском проблему ( y зависности од природе администрације), Србија не може да очекује неку генералну промену става у односу на статус КиМ. Два су основна разлога за то. Пре свега, оваква ситуација у региону је највећим делом последица америчке спољнополитичке активности и САД сигурно неће дозволити другачије решење, јер би то било јавно признање неуспеха. С друге стране, амерички метод решавања сложених етничких и историјских проблема не може бити плодотворан у овим условима. Брзе, грубе и нагле одлуке које у основи имају економску, а не политичку садржину могу само краткорочно да дају резултат, и то искључиво уз успостављање спољњег мониторинга и контроле.

\section{Србија и НР Кина}

Нема никаквих основаних разлога за сумњу у то да ће Народна Република Кина (НРК) доминирати у свету током 21. века. О томе сведоче многи фактори: брз економски развој, њен стратешки потенцијал, огромно унутрашње тржиште, грандиозне инвестиције у инфраструктуру, образовање, научна истраживања и достигнућа, као и незадрживо нарастање војне моћи. То практично значи да са политичког и економског аспекта полако улазимо у век Источне и Југоисточне Азије.

Евидентно је да се Кина налази на узлазној путањи своје геостратегијске моћи. Тај успон не може у потпуности да се изрази квантитативно, али и основни показатељи економског и општег прогреса говоре о неизбежности промена на глобалној слици света. Посебан значај за позицију ове земље у међународном поретку има чињеница да Кина припада веома уском кругу привилегованих земаља које могу да воде самосталну унутрашњу и спољну политику. Немогућност спољне контроле пораста потенцијала НРК посебно брине Америку, која данас отворено сматра Кину свогим главним стратегијским противником и чини све како би максимално отежала њен даљи развој. 35

Присуство НР Кине на Балкану за сада одликују чисто економски интереси. Синтагма „за сада“ је овде кључна, будући да су кинеске компаније и инвеститори непосредно укључени у развој регионалне инфраструктуре, транспорта, пољопривреде, телекомуникација и финансијског сектора, односно у подручја која су од суштинског значаја за одрживост савремене државе.

Пресудни импулс развоју односа између Кине и Србије дао је мултилатерални формат сарадње „16 + 1“, који је Пекинг предложио 2012. године. Ова иницијатива део је кинеске трансконтиненталне економске и геополитичке визије -

35 Видети шире у: Младеновић, М. и Цветковић, В. (2015). Савремени руско-кинески односи. Годишњак Факултета безбедности, 2015, 41-51. 
ажурирана верзија кинеске спољнополитичке стратегије „Иди напоље“.36 Ова идеја подразумева дубљу интеграцију земље у светску економију и, у коначном, обезбеђење лидерства у њој. ${ }^{37}$

Земље укључене у пројекат $16+1$ пролазе кроз два главна „пута будућности“ Економски појас Пута свиле и Морски Пут свиле. Изградњу „Балканског пута свиле“ Кина је започела улагањима у луку Пиреј, видећи Грчку као улаз у Европу преко Балкана. Други велики пројекат је брза пруга Београд - Будимпешта у дужини од 350 км, са буџетом од 2,9 милијарди долара. Главни инвеститор мађарског и српског дела пруге је кинеска Екимбанк, а српску деоницу ће градити руска компанија «РЖД» („Руске железнице“). ${ }^{38}$

Истовремено, за Србију и друге земље региона кинески кредити су важни у условима недостатка повољнијих алтернатива из ЕУ. Њима се обезбеђује финансирање огромних инфраструктурних потреба региона, због чега се занемарује чак и ризик од дужничке зависности.

Када анализирамо балканску политику, не треба заборавити да су кинеске инвестиције стратешког карактера. Оне нису оријентисане само на економске, већ и на политичке резултате. Укљученост у регионалне пројекте на Балкану може помоћи јачању гласа НРК-а у Бриселу, што изузетно брине поједине чланице Европске уније.

За сада, на Балкану нема директног и отвореног ривалитета између Русије и Кине. Обе државе следе своје интересе, који се још увек не преклапају. То значи да проблеми не настају у економији, али се могу појавити у настојањима позиционирања сопственог имиџа. Кина постепено, али доследно, истискује Русију као главну алтернативу Србије Западу. Скривена конкуренција између Кине и Русије за положај главног неевропског актера на Балкану само ће се убудуће повећавати, али ће највероватније бити у границама „фер-плеја“. Историјски, односи Кине и Русије никада нису били једноставни. Било је много проблема и тешко решивих питања, али никада није дошло до међусобног ратног сукоба. Речена историјска чињеница делује помало нестварно ако имамо у виду развој једног и другог царства и потоњих држава, као и сличне историјске примере на другим крајевима света. Независно од разлога који су условили такво

36 На трећем заседању Свекинеског народног конгреса, 2000. године донета је стратегија активног учешћа кинеских произвођача на светско тржиште, под називом „Иди напоље“. Поред идеје да се кинеске фирме појаве у другим земљама, да се омогући експорт радне снаге и одлазак грађана у иностранство, основни циљ овог решења је био да НР Кина до 2020-2030. постане најјача економија света, а да до 2020. године повећа обим свог ДБП 4 пута.

37 Zeneli, V. What Has China Accomplished in Central and Eastern Europe? // The Diplomat, November 25, 2017,https://thediplomat.com/2017/11/what-has-chinaaccomplished-incentral-and-easterneurope, 09/05/2020.

38 Глинкина С.П., Куликова Н.В., Тураева М.О., Голубкин А.В., Яковлев А.А. Китайский фак-тор в развитии стран российского пояса со-седства: уроки для России. Научный доклад. М.: Институт экономики РАН, 2018. С. 42. 
стање ствари, извесно је да одсуство ратног наслеђа омогућава савременој Русији и Кини да своје односе уређују искључиво на прагматичним темељима - у складу са властитим економским и другим интересима који функционишу изван постулата политичке идеологије или вредносних претпоставки култура.

И док Кина незаустављиво постаје економски хегемон света, војно ревитализована Русија постаје равноправни политички актер у светским играма моћи. На том трагу ваља сагледати данашњу и будућу сарадњу Кине и Русије „партнерство“ које ће свагда функционисати у балансирању између рационалног савезништва и тињајућег ривалства. То није зближавање на некаквим „заједничким вредностима“ већ сарадња заснована искључиво на прорачунатим узајамним уступцима. ${ }^{39}$

Поред економског значаја који има кинеско присуство, оно је важно и са геополитичког аспекта. Пекинг је за Србију важан „као алтернатива безусловној оријентацији и потчињености евроатлантском свету: он не представља претњу, ни као хегемон, нити као радикална сила“.40 Другим речима, Кина се на Балкану не појављује као „царство по позиву“. Једноставно речено, кинеске компаније су спремне да раде и са „филима“ и са „фобима“, без обзира на то у ком делу света леже њихови корени. Просечног Србина за Кину вежу одређена позитивна очекивања: очување и отварање нових радних места, развој инфраструктуре, јефтина роба, социјални лифтови, географска мобилност и др. Кина „улази“ на Балкан, не само зато што има стратегију, већ и што решава тактичке задатке. Почетак кинеске експанзије везан је за модернизацију старих и изградњу нових европских лука и инфраструктурних објеката у оквиру пројекта „Један појас, један пут“.

У ту тактику је укључен и развој балканског и српског тржишта. За Србију, као малу државу, и државу која је карактеристична по томе што је чешће објекат него субјекат на међународној сцени, кључни принципи којих се Кина придржава у међународним односима много су прихватљивији од оних које форсирају Сједињене Државе. Ту се пре свега мисли на: могућност вођења независне и вишевекторске спољне политике, тежњу за неконфликтним односима, вођење спољнополитичких акција на основама међународног права, придржавање циљева и принципа Повеље УН-а, укључујући неповредивост граница и територијални интегритет држава, решавање спорова и сукоба политичким средствима, одбацивање двоструких стандарда, итд.

39 Видети шире у: Младеновић, М. и Цветковић, В. Оп. цит.дело, стр. 42.

40 Энтина Е., Пивоваренко А., Новакович Д. Куда идут Балканы? / Доклад Международного дискуссионного клуба «Валдай». 2018. http://ru.valdaiclub. com/files/21567/, /09/05/2020. 


\section{ЗАКЉУЧАК}

Захваљујући свом геостратешком положају, Србија је чврсто уплетена у многе чворове светске политике. Штавише, у зависности од специфичних историјских околности, Србија је често бивала језгро озбиљних геополитичких трансформација (Балкански ратови с почетка и краја 20. века, Први светски рат, модерна криза). Заузимајући централно место у рубном региону међународне политике, где се сударају светске религије и културе и где се мешају и настају нове нације, Србија је кроз своју историју, уз краткотрајне искораке и приближавања појединим значајним геополитичким факторима, покушавала да задржи мултивекторску позицију.

Распад биполаризма не само да није довео до успостављања стабилнијих и безбеднијих међународних односа, већ је, напротив, кореспондирао са највећом несигурношћу и неизвесношћу људског рода од времена Другог светског рата. После нестанка „контрабаланса“ дошло је до отвореног политичког, економског, па и директног војног мешања земаља НАТО у суверенитет многих земаља. Као резултат оваквог стања, конфликтни потенцијал у свету, не само да није ослабио, већ се, напротив, знатно повећао. 41

Упркос чињеници да су многе «постсоцијалистичке» земље промениле рухо и из једног пакта прешле у други, Србија је и даље на раскрсници. Та неодређеност данас много теже опстаје и сложеније ју је сачувати од релативне неутралности коју је бивша СФРЈ обезбеђивала у биполарном свету. Поред старих спољнополитичких изазова и оријентација којима теже поједине политичке снаге српског друштва (ЕУ, НАТО), у новим међународним околностима намеће се још један субјект који раније није био у понуди.

Чини се да данас Кина, а не ЕУ, може да постане интегратор Европе „различитих брзина“. Финансијска подршка вишеструким форматима земаља Евројуга, гранска и улагања у логистику, превасходно у енергетику, транспортну и телекомуникациону инфраструктуру у зглобним тачкама региона (луке, железничке пруге, погранични градови), омогућавају Пекингу да буде „куратор“ важних економских процеса који, заузврат, могу постати темељ нових политичких одлука ${ }^{42}$.

Имајући у виду све наведено, мултивекторност за Србију ипак представља политику преживљавања која омогућава не само да задржи status quo у најосетљивијем - косовском - питању, него и да створи политичку, економску и војно-техничку основу за будуће „праведније“ решење.

41 Видети шире у: М. Младеновић, Е. Пономарева, Кина-Америка-Русија - глобални троугао 21. века, Социолошки преглед, Београд, YU ISSN 0085-6320, UDK 316,2011, вол. 45, бр. 4, стр. 459-476,

42 Видети шире у: Пономарева, Е. Г. и Младенович, М. Сербия: Многовекторность как выход из тупика старегической уязвимости, Сравнителная политика . 2020 Т.11 № 1, Москва, eLIBRARY ID: 32289, стр. 88-103. 


\section{БИБЛИОГРАФИЈА:}

1. Агенција LIFE, Глава МИД ФРГ: Сербия должна признать независимость Косова для вступления в EC, https://life.ru/p/1089227;

2. Angela Merkel: No Balkan Border Changes, https://www.politico.eu/article/angelamerkel-no-balkan-border-changeskosovo-serbia-vucic-thaci;

3. Борисов А.В. Косово получило свою армию //Российская газета, 14 декабря 2018, https://rg.ru/2018/12/14/kosovopoluchilo-svoiu-armiiu.html;

4. Вишняков Я.В., Пономарева Е.Г. Сербия на Балканах: изобретение «порохового погреба Европы» // Современная Европа. 2018. № 7;

5. Western Balkans: Between East and West. Public Opinion Research in Bosnia and Herzegovina, Macedonia, Montenegro, and Serbia / National Democratic Institute, 2018. https://www.ndi.org/sites/default/files;

6. Глинкина С.П., Куликова Н.В., Тураева М.О., Голубкин А.В., Яковлев А.А. Китайский фак-тор в развитии стран российского пояса со-седства: уроки для России. Научный доклад. М.: Институт экономики РАН, 2018;

7. Декларация о стратегическом партнёрстве между Российской Федерацией и Республикой Сербией http://www.kremlin.ru/supplement/1461;

8. Энтина Е., Пивоваренко А., Новакович Д. Куда идут Балканы? / Доклад Международ-ного дискуссионного клуба «Валдай». 2018. http://ru.valdaiclub. com/files/21567/;

9. Zeneli, V. What Has China Accomplished in Central and Eastern Europe? // The Diplomat, November 25, 2017, https://

thediplomat.com/2017/11/what-has-china-accomplished-incentral-andeastern-europe/;

10. ИА «Новороссия», Гайич С.: Обострение в Косово - очередной этап войны Запада против Сербии и России, https://novorosinform. org/713850;

11. Istraživačko-izdavački centar Demostat, Više žele u Evropu nego da im zemlja uđe u EU http://demostat.rs/sr/vesti/istrazivanja/vise-zele-u-evropu-nego-da-imzemlja-ude-u-eu/660;

12. ISIS-Daesh Training Camps in Kosovo, Recruitment of Terrorists by NGOs, http://www.globalresearch.ca/isisdaesh-training-camps-in-kosovo-recruitmentofterrorists-by-ngos/5537652;

13. Istraživanje: Vučić ubedljivo najpopularniji političar, Putinu najviše poverenja među svetskim liderima, http://www.novosti.rs/vesti/naslovna/politika/aktuelno.289.html:769462;

14. Kojem bi se carstvu priklonili... Srbija između Istoka i Zapada. Avgust 2017, http://demostat. rs/sr/vesti/istrazivanja/kojem-bi-se-carstvu-priklonili--srbijaizmedu-istoka-i-zapada/214;

15. Lundestad, G. Empire by Invitation? The United States and Western Europe, 19451952 // Journal of Peace Research, 1986, Vol. 23, No. 3, pp. 263-277;

16. М. Младеновић, Е. Пономарева, Кина-Америка-Русија - глобални троугао 21. века, Социолошки преглед, Београд, YU ISSN 0085-6320, UDK 316,2011, вол. 45, бр. 4, стр. 459-476;

17. Мирослав Младеновић, Јелена Пономарева, «Мека моћ» Русије - као услов успеха евроазијске интеграције, Српска политичка мисао број 1/2016 год. 23. vol. 51, Београд, УДК 327::911.3(497)“19/20“, стр. 11-29; 
18. Младеновић, М. и Цветковић, В. (2015). Савремени руско-кинески односи. Годишњак Факултета безбедности, 2015;

19. Mladi i politika (Youth and Politics). Mode of access: http://demostat.rs/sr/vesti/istrazivanja/ mladi-i-politika/718;

20. Нидерланды требуют отменить безвизовый режим ЕС для Албании, (https://sputnikgeorgia.ru/world_politics/20190604/245465012/;

21. Пономарева Е.Г. Албанский фактор дестабилизации Западных Балкан // Вестник МГИМО-Университета. 2018. № 2(59);

22. Пономарева,Е.Г. и Младенович, М. Сербия: Многовекторность как выход из тупика старегической уязвимости, Сравнителная политика . 2020 Т.11 № 1, Москва, eLIBRARY ID: 32289, стр. 88-103;

23. Пономарева Е.Г. Проект «Косово» и большая политика // Мир и политика. 2013. № 7 (82);

24. Пресс-конференция В. Путина и А. Вучича. 17 января 2019.г, http://www.kremlin.ru/events/president/ news/59693;

25. Пресс-конференция В. Путина и А. Вучича. 17 января 2019 г., http://www.kremlin.ru/events/president/ news/59693;

26. Пудовкин Е. Гибкая граница, https://www.rbc.ru/politics/29/08/2018/5b86769b9a7947866771c72f;

27. Саопштење Комисије упућено Европском парламенту, Савету, Европском економском и социјалном комитету и Комитету региона, https://www.mos.gov.rs/public/ck/uploads/files/EU\%20Strategija\%20prosirenj a\%20zapadni\%20Balkan\%202018.pdf,

28. Survey of Serbian Public Opinion / International Republic Institute (IRI). Mode of access: https://www.iri.org/sites/default/files/wysiwyg/serbia_ november_2015_poll_public_release.pdf;

29. Shared Vision, Common Action: A Stronger Europe. A Global Strategy for European Union's Foreign and Security Policy. European Union External Action. June 2016. Mode of access: https://eeas.europa.eu/sites/eeas/files/eugs_review_web.pdf;

30. Tači preti EU formiranjem „Velike Albanije“, https://www.telegraf.rs/vesti/ politika/3066812-tacija-preti-eu-formiranjemvelike-albanije-ako-ne-zele-daprihvati-dvealbanske-drzave-sa-dve-zastave-neka-prihvatesamo-jednu-zastavu;

31. Три сценария для Косово. Аналитический доклад / под ред. О. Бондаренко. Режим доступа: https://balkanist.ru/tri-stsenariya-dlya-kosovo;

32. Final Declaration by the Chair of the Conference on the Western Balkans. Berlin. 28 August 2014., https://www.auswaertigesamt.de/blob/264688/953e9f4b2f0b008d20bf6a65bfb 4ebbe/140828-abschlusserkl-konf-westl-balkan-data.pdf;

33. Colomer , J.M. Great Empires, Small Nations: The Uncertain Future of the Sovereign State. L., N.Y.: Routledge, 2007;

34. Country Reports on Terrorism 2017., https://www.state.gov/reports/countryreports-onterrorism-2017; 


\section{NEW (GE0)POLITICAL CROSSROADS FOR SERBIA}

As many times in history, the Balkans is still a zone of strategic regrouping and competition. The struggle of the leading actors in world politics is especially focused on, in political and military sense, still relatively neutral Serbia. Despite serious upheavals at the turn of the $20^{\text {th }}$ and $21^{\text {st }}$ centuries (bloody dismantling of Yugoslavia, NATO aggression, "divorce" with Montenegro, creation of the "Republic of Kosovo"), Belgrade still manages to balance between the two main poles of attraction: the EU and NATO, on the one hand, and Russia, on the other, which fits into the concept of its multi-vector foreign policy. Despite the geographical, historical, cultural and economic destiny for European integration, Serbia's final choice for this option is burdened by two very important points: the need to recognize the "Republic of Kosovo" and (which is currently less explicit but certainly present), to include itself into the NATO militarypolitical framework. The first issue comes with significant political and civilizational risks, both for the Western Balkans and for the entire European Union, and there is a serious internal rift in Serbian society regarding the possibility of recognizing a new Albanian entity. The second moment is burdened with still fresh memories of the anticivilization aggressive combat actions of NATO countries. The natural balance of EuroAtlantic pressure on Belgrade is Russia. It has unique opportunities to create a good image and, unlike the EU, does not have the characteristics of a "kingdom by invitation". However, the existing historical dualism is disrupted by the emergence of a new player in the Balkans - the People's Republic of China (PRC). Beijing exclusively uses economic levers to solve the strategic tasks of penetrating European markets and at the same time smoothly, but very successfully, pushes Russia out as the main alternative to Serbia's Western orientation.

Keywords: Serbia, European Union, NATO, Russia, People's Republic of China, foreign policy, neutrality 